This is an electronic version of an article published in Esmonde, I., \& Caswell, B. (2010). Teaching mathematics for social justice in multicultural, multilingual elementary classrooms. Canadian Journal for Science, Mathematics, and Technology Education. 10 (3), 244-254. Cognition and Instruction is available online at: www.tandfonline.com<http://www.tandfonline.com/> with http://www.informaworld.com/openurl?genre=article\&issn=1492$\underline{6156 \& \text { volume }=10 \& \text { issue }=3 \& \text { spage }=244}$

\title{
Teaching Mathematics for Social Justice in Multicultural, Multilingual Elementary Classrooms
}

\author{
Indigo Esmonde \\ Beverly Caswell \\ University of Toronto
}


TEACHING MATHEMATICS FOR SOCIAL JUSTICE

\begin{abstract}
This article describes a set of collaborative inquiry projects that emerged from a research study group involving teachers, university researchers (the authors), and school district staff as they worked to teach mathematics equitably in an urban elementary school. The project is analyzed using Marilyn Cochran-Smith's six principles of pedagogy for teaching for social justice. In the study group, teachers were involved in designing research questions to honour their students' cultural and community knowledge and to develop mathematics teaching with a social justice focus. We offer three examples of teaching mathematics for social justice in diverse classrooms, and consider the broader implications of inquiry projects such as these.
\end{abstract}


TEACHING MATHEMATICS FOR SOCIAL JUSTICE

\section{Teaching Mathematics for Social Justice in Multicultural, Multilingual Elementary Classrooms}

Teaching mathematics equitably is a complex and difficult task, not least because of the multiplicity of competing interests and definitions for equity that are currently in use in mathematics education. While some focus on closing achievement gaps based on race, gender, socioeconomic status, or special education status, others argue for a more culturally inclusive mathematics curriculum (D'Ambrosio, 1997; Masingila \& King, 1997), or for classroom participation structures that mirror children's out-of-school communities (Brenner, 1994).

In this paper, we report on a series of collaborative inquiry projects in which we, as university researchers, worked with a group of teachers and school district staff to investigate how to teach mathematics equitably in one urban elementary school. We present some of the ways in which our group conceptualized the equity issues we faced, discuss the pedagogical and curricular decisions we made, and end by considering the possible broader impact of this collaborative project on teaching and learning at the school and in the district. We begin with a literature review detailing some of the research addressing various approaches to teaching mathematics equitably and for social justice, and then describe the collaborative inquiry projects and our research methods in more detail.

\section{How can mathematics education contribute to social justice?}

Although concerns for equity have become ever more central within mathematics education, there is still little consensus on how the term should be defined or how to effectively work towards equity in classroom learning. In our paper, we use the terms 


\section{TEACHING MATHEMATICS FOR SOCIAL JUSTICE}

'equity' and 'social justice' relatively interchangeably, since our view is that mathematics education should contribute to broader struggles for social justice. Precisely how mathematics education can make this contribution has been a subject of some debate within the field.

First and foremost, discussions of equity usually begin by references to achievement gaps that plague U.S. and Canadian schools. These gaps in mathematical achievement (as measured by standardized tests, rates of course-taking, or graduation rates) are related to gender, race (with White students and students of Asian descent, on average, achieving at higher rates), and socioeconomic status (with wealthier students achieving at higher rates) (Lee, 2002). A key goal for many mathematics education researchers is to close these achievement gaps, or, in other words, to be "unable to predicate students' mathematics achievement and participation based solely upon characteristics such as race, class, ethnicity, gender, beliefs, and proficiency in the dominant language" (Gutierrez, 2007, emphasis in original).

However, as Gutierrez (2008) points out, equity initiatives that rely solely on arguments about achievement gaps can be dangerous, as they can perpetuate deficit notions of marginalized students and position dominant groups as the norm to which others should aspire. In addition, these arguments can suggest that our work is done when the gaps close. As a current example, consider the case of gender. There has been some debate about whether gender gaps have closed, or in fact, reversed, in recent years. Thus, recently there have been some initiatives aimed at improving boys' achievement. These initiatives ignore research that suggest that mathematics classrooms may still be 


\section{TEACHING MATHEMATICS FOR SOCIAL JUSTICE}

constructed as masculine spaces that position girls as outsiders, even girls who are achieving well (Walshaw, 2005).

Alternative conceptualizations of equity and social justice challenge both the content (what should be taught) and pedagogy (how it should be taught) in mathematics classrooms. Within these conceptualizations, academic excellence is taken as necessary, but not sufficient, for equity. These alternative conceptualizations often draw on research from the traditions of multicultural education (Banks \& Banks, 1995), culturally relevant pedagogy (Ladson-Billings, 1995) and Freirean pedagogy (Freire, 1993). These traditions have been more fully developed in other subjects - particularly literacy - than they have in mathematics, but a broad cross-section of mathematics teachers and researchers have begun the work of considering how to adapt these approaches to the specifics of mathematics teaching and learning at various levels and in a number of contexts.

Some recurring themes have begun to emerge in this research, including: pedagogies that provide a common ground of experience for students and that allows students to describe and define mathematics on their own terms (Moses \& Cobb, 2001), pedagogies that draw on student and community resources to connect to community funds of knowledge (Civil, 2007; Gonzalez, Moll, \& Amanti, 2005), and pedagogies that bring social justice issues into the classroom and use mathematical tools to investigate them (Gutstein, 2006). Each of these approaches considers how the content, the context, and the pedagogy of mathematics might change.

Because of the complexity of teaching for social justice, we have found CochranSmith's (2004) six principles of teaching for social justice to be helpful, as these principles are expansive and include all of the concerns that have been addressed in the 


\section{TEACHING MATHEMATICS FOR SOCIAL JUSTICE}

literature reviewed here. These six principles include: enabling significant work in a community of learners, building on students' cultural knowledge and interests, teaching skills and bridging gaps, working with families and communities, diversifying assessment, and making activism an explicit part of the curriculum. ${ }^{1}$ We have found that when we use the term teaching mathematics for social justice, people often think about the last principle - making activism and social justice issues part of the mathematics curriculum. In fact, we cannot achieve this last principle without careful attention to what and how mathematics is taught in the classroom and thus, the first five principles are equally important for mathematics teaching.

Therefore, we will use these six principles as an analytic frame to understand the teacher/researcher inquiry projects that we discuss in this paper. While we and the teachers came together as a group because of a shared interest in using a social justice approach to mathematics teaching, over time we considered all six principles in our efforts to teach for social justice in an urban, multicultural, multilingual elementary school. Our goal in this paper is to present the three examples of classroom inquiry that came out of our professional development project, and to highlight how these three examples demonstrate principles of teaching for social justice in the area of elementary mathematics.

\section{Methods}

This paper reports on a pilot study of professional development. We were the two facilitators for a year-long collaborative project with a group of teachers and staff at a diverse, urban, elementary school identified as underperforming in provincial literacy and

\footnotetext{
${ }^{1}$ These principles will be discussed in much more detail in the results section of the paper.
} 


\section{TEACHING MATHEMATICS FOR SOCIAL JUSTICE}

numeracy scores. At the beginning of the academic year, we approached the school and invited school staff members to join our 'Radical Math study group' to investigate equity issues in mathematics teaching. Participants who volunteered included ourselves (a university professor and a graduate student instructor), a second graduate student (with expertise in mathematics education for English Language Learners), the school principal, five elementary teachers from grades kindergarten through fifth grade, two teacher candidates from our university, a teacher-librarian, a community support worker, and an instructional leader in mathematics from the local school board.

The School is located in one of the city's high needs neighbourhoods, and has 450 students in grades Kindergarten to grade 5. Within the student and family population, there were thirty languages spoken and thirty-five countries represented. The school was part of a network of 109 inner city schools in which teachers participated in in-school professional development through "Teaching and Learning Critical Pathways" (TLCP), a school board initiative developed as an effort to improve students' literacy and numeracy scores. As well, the school was one of seven schools in the board that was provided with extra funding to help provide academic and social support to the families and communities, and to share their innovative practices to help other local schools develop successful practices.

Over the course of the year, the study group met approximately once a month for an afternoon during school. At early meetings, we brainstormed a set of issues that participants were concerned about in their school and in the district, with respect to equitable mathematics teaching. We then selected a few issues to work on, and teachers developed inquiry projects related to these issues. By midway through the year, we spent 


\section{TEACHING MATHEMATICS FOR SOCIAL JUSTICE}

most of the PD time working in smaller inquiry groups designing, implementing, and reflecting on the projects. These were not formal action research projects, but the groups were encouraged to collect some form of data to help them learn more about their issue of concern. The issues that teachers selected were: appropriate mathematics pedagogy for English Language Learners (ELLs), teaching concepts of volume and capacity in ways that went beyond rote and procedural, and connecting mathematics curriculum to the community.

Because this was a pilot project, we did not collect data throughout. We collected agendas and notes from the meetings themselves, and then obtained consent from the participants to videorecord our last meeting, in which each group reported on their inquiry projects. In this paper, we analyse the participants' reports from this videorecording, and provide some information about the types of activities we engaged in throughout the PD sessions. The participants' reports allow us to examine how teachers represented their equity-focused work to one another. As a result, we have very little data of classroom implementation of these projects (and therefore, of student learning). This represents a limitation of the study, but we focus primarily on how participants (including ourselves) framed the issues and conceptualized how best to teach for social justice.

Analysis of the video of teacher presentations, and of the study group artifacts, was framed by Cochran-Smith's six principles of pedagogy for social justice (CochranSmith, 2004). In the initial phase of analysis, transcripts from the videorecorded session were read in their entirety and coded according to our understanding of Cochran-Smith's six principles, each one constituting a heading or category. We then met and compared coding. Any discrepancies were discussed for clarification. This process involved 
TEACHING MATHEMATICS FOR SOCIAL JUSTICE

working back and forth between the data and revisiting our understanding of the six pedagogical principles. It is important to note that the study group was not organized around Cochran-Smith's six principles, and our analysis of the study group projects should not be seen as an evaluation of whether or not teachers met all the six principles. Instead, we found the principles to be an effective way to organize our own and other participants' thoughts about equity in their teaching, and allowed us to consider which issues were on the table at various points throughout the project.

For this paper, we focus primarily on how the three inquiry projects exemplify various principles of teaching for social justice in the context of an urban elementary school. (While these projects were not perfect and all participants, including us as facilitators, felt there were some aspects we would have liked to improve, in this paper we focus on the successes of the project - how we collectively built tighter connections between teaching for social justice and routine classroom activities at this school.) We begin by describing the three projects, and then outlining each of the six principles and discussing how these projects provide examples of all but one of these principles. We end with a consideration of the broader impact of the study group for participants and for the school.

\section{Three Inquiry Projects from the Radical Math Study Group}

\section{The Water Project}

Participants in the water project initially included one university researcher (Caswell), two fifth-grade teachers, and one school board instructional leader for mathematics. Two teacher candidates from a nearby university joined the team partway through the year and helped to design and implement the classroom activities. 


\section{TEACHING MATHEMATICS FOR SOCIAL JUSTICE}

The water project was so called because the fifth grade students and teachers had been working for the year on the "big idea" of human rights and children's rights, and had narrowed their focus to water as a human right. Through their involvement in the Radical Math study group, this group of teachers/researchers integrated mathematics curriculum topics of volume and capacity, along with other mathematical topics multiplication, division, and proportional reasoning into this big idea.

The integration of mathematics topics related to water rights occurred in two major ways:

1. The students kept water logs to track how much water they and their families used on a daily basis, and participated in water rationing challenges in which they problem-solved how they would use water if they were limited to only 400L per day for a family.

2. The class constructed what they called a "water line" in the hallway, and students took turns carrying large, heavy jugs of water back and forth across the line based on one family's water consumption (from the water log data). Collectively, they computed the amount of time it would take to carry that amount of water over a long distance, just as some children in developing countries have to carry water for their families. They invited other students and family members to carry water along the water line during the school's spring Open House.

In addition, the class engaged in a number of related activities in their social studies and English classes. They read about the lack of access to clean water in some Aboriginal communities in Ontario, and created dramatic presentations to illustrate this issue. They created multimedia presentations and a series of posters to encourage water conservation. 
TEACHING MATHEMATICS FOR SOCIAL JUSTICE

\section{The Languages Project}

Participants in the language project included one university researcher (Miwa Takeuchi), one fourth-grade teacher, and the lead teacher for the school (a former ESL teacher). The fourth grade students had been studying an overarching theme of "diversity makes us stronger" in many of their subject areas. The languages project was designed to integrate the theme of diversity with a study of the many languages spoken throughout Canada, the province of Ontario, the city of Toronto, and the school. This group of teachers/researchers integrated mathematics curriculum topics from the data management strand into this big idea, including data collection and the creation of bar graphs.

The integration of mathematics topics related to a language census occurred in two major ways:

1. The classes studied data that the teachers had located about the major "mother tongues" spoken in Canada, broken down into percentages. They also studied data about percentages of language spoken in Ontario and Toronto.

2. The classes collected data from every other class in the school about the languages spoken at home, and represented this data through tally charts and bar graphs.

In the languages project, the teachers were not able to integrate the mathematical topics with other subject areas because other subject areas were taught by different teachers who were not necessarily focusing on language diversity.

\section{The Number Book Project}

Participants in the number book group included a university professor, a second grade teacher, a kindergarten teacher and a community support worker. The number 
TEACHING MATHEMATICS FOR SOCIAL JUSTICE

project was designed to learn about and then build instruction on the families' and community's mathematical knowledge. The group asked children and their parents to share number stories, songs and games that parents knew as children. They then planned to design classroom activities that drew on one or more of these number stories, songs or games.

The integration of mathematics topics related to family and community number knowledge occurred in two major ways:

1. The project began with the grade two teacher and kindergarten teachers sending a letter home to parents inviting them to share with their child any number games, chants or songs that they remembered from their own childhood.

2. Because there were no responses from the letter sent to the kindergarten families, the kindergarten teacher invited one of the grade two students to share his poem with the kindergarten students. That poem was then used as the basis to create a classroom counting/number book for the kindergarten students. Twenty of the kindergarten children were assigned a number (from 1 through 20) for which they had to create a page including a picture that represented the number. The book was made available to the whole class, and all the kindergarten students participated in several activities around the poem and the number book.

In the number book project there were no follow-up activities with the second grade class, and no integration of the number book activities with other subject areas.

\section{Principles of Teaching for Social Justice in the Inquiry Projects}

These three inquiry projects were all designed in attempts to integrate social justice issues and equitable teaching into mathematics instruction in K-5 classrooms. We 


\section{TEACHING MATHEMATICS FOR SOCIAL JUSTICE}

believe that various aspects of these projects exemplify Cochran-Smith's six principles of teaching for social justice. In this section, we elaborate on each of these principles and explain how the inquiry projects relate to them.

Principle 1: Enable significant work within communities of learners. This

principle includes assuming that all students are capable of dealing with complex ideas, providing opportunities for students to learn academically challenging knowledge and skills, and fostering a shared sense of responsibility for learning within collaborative groupings.

The languages project provides a compelling example of Principle 1 . The whole fourth-grade class worked as a group to collect the data from various classrooms, to compile it, and then to represent it in various forms. Each student was thus responsible for a portion of the whole. In addition, the mathematical work was challenging and students were not given direct instructions about how to represent what they found. Instead, once the data were collected, students were simply asked "How can we make these numbers into charts?" Choosing an appropriate representation for their data was a challenging task for fourth-grade students and one that focuses on ideas central to data management. There was also some evidence that the mathematical task was very meaningful to students. Several students connected the data represented on the graph with their school context, through identifying the people represented by a particular bar (e.g., connecting the bar representing two people who spoke Vietnamese by saying "it's myself and my cousin," or wondering which students were represented by a specific bar).

The water project puts an interesting spin on Principle 1. In their presentation about their inquiry project, this study group emphasized the efforts they had put towards 


\section{TEACHING MATHEMATICS FOR SOCIAL JUSTICE}

learning the mathematics of volume and capacity together, in order to better teach it to their students. In effect, the teachers themselves formed a collaborative community and all took responsibility for their shared learning around this topic. They repeatedly emphasized that they wanted to learn and focus on the big ideas of this topic, to understand it deeply, and that they wanted this for their students as well. We feel that their efforts to understand the mathematics deeply is a necessary component of Principle 1.

Finally, the number book project was particularly concerned with creating engaging and meaningful mathematics experiences that went beyond rote counting. They wanted "to use the stories, songs and games in ways that wasn't just rote learning and it wasn't just about memorizing a number sequence" (transcript, 05/20/2009, 37:14). This relates to Principle 1 because this group was focused on not 'dumbing down' the curriculum.

We found participants' discussions of Principle 2 were interconnected with discussions of Principle 4, and so we discuss these two principles together.

Principle 2: Build on what students bring to school with them-knowledge and interests, cultural and linguistic resources. This principle includes acknowledging, valuing and working from the cultural and linguistic resources as well as the interests and knowledge of students, and developing classroom participation structures that are culturally and linguistically congruent with those of the students.

Principle 4: Work with (not against) individuals, families, and communities. This principle includes drawing on family histories, traditions, and stories, demonstrating 
TEACHING MATHEMATICS FOR SOCIAL JUSTICE

respect for all students' family and cultural values, and demonstrating a connection to students and their communities.

All three of the inquiry projects tried to build on student or community interests or knowledge in some way. The water project was designed to address students' interest in water rights, the languages project was designed to honor the multiple languages in the community, and the number book project tried to build on parents' mathematical knowledge while allowing kindergarten students to tailor a number book to their own interests.

The water project also allowed for some unanticipated connections to students' lives. For example, some fifth grade students had direct experience with a lack of access to clean water. In one of the fifth grade classes, during an activity related to the water line a Rwandan student spontaneously told the class about his experiences carrying water. In the other class, a student became very upset when he dropped the water bottles while walking the water line; later, he told the teacher and teacher candidate that when he was young he used to have to carry very heavy jugs for his family. Although teachers did not set out to connect to this aspect of their students' lives (because in fact they did not know about these experiences), their classrooms were open enough that students could share if and when they wanted to. Finally, the use of the water line at the family Open House was an innovative way to connect parents with the activities that students were doing in the classroom. The water line was the most popular activity at the school's Open House, with clusters of children and parents grouped around it encouraging one another as they carried the heavy jugs. 


\section{TEACHING MATHEMATICS FOR SOCIAL JUSTICE}

In this multilingual school, teachers were keenly aware that their teaching practices could disadvantage students whose families spoke languages other than English at home. As a result, the languages project was directly aimed at tapping into the resources that these students and their families brought to school, rather than focusing on what students and their families lacked. The purpose of the project, from the classroom teachers' perspective, was to help students see their own languages represented in the charts. In the school survey part of the project, students seemed to take great pride in representing their own and their families' languages on the chart. For example, when students were creating the various bars of the bar chart, some students would ask questions like "Can I do Bengali? Or can I do Vietnamese? Because I love my country" (for more details on the transformation of ELL students' participation throughout this project, see Takeuchi \& Esmonde, 2010).

The purpose of the number book project presentation was to draw on and honour families' cultural experiences and to use children's communities as a basis for mathematics instruction in kindergarten and grade two. Although the teachers did not receive the response that they had hoped for, they were still able to select some community mathematics that could be used for kindergarten activities. The creation of the number book itself was another example of connecting mathematics instruction to children's interests, since children drew objects that they liked or were connected with: one of the students "drew her family because there are four people in the family". Another student who chose number eight asked the teacher to take a photo of a spider, since the class had been studying spiders. 


\section{TEACHING MATHEMATICS FOR SOCIAL JUSTICE}

Principle 3: Teach skills, bridge gaps. This principle includes learning where and how to help students connect what they know to what they do not know and use prior skills to learn new ones. This principle also emphasizes the need to listen closely to students to make sense of their thinking.

The number book project connected to Principle 3 because of the way the book was used once completed. A member of this inquiry group sat with several of the kindergarten children and had them go through the book with her. The children counted and discussed which of the pages they liked best and why. The book provided an opportunity to listen to children's counting activities and to observe the way they used features of the pictures to help them in their counting. The study group discussed these observations and considered the implications for further instruction. For example, the group noticed that many children clustered their drawings in sets of five, and the kindergarten teacher explained this had been a feature of her instruction. The group also noticed that children preferred the pictures that were arranged in arrays, and speculated that these arrays might have facilitated their counting. Children's work on the number book provided an opportunity for the group to listen closely for evidence of student thinking around numbers.

Principle 5: Diversify forms of assessment. This principle includes using a wide variety of evaluation strategies for assessments, and especially not relying on standardized tests as the sole or primary form of assessment.

This principle did not come out in the group presentations about the inquiry projects. We believe that this principle was not discussed because the brevity of the presentations encouraged teachers to focus mainly on the large-scale activities in the 
TEACHING MATHEMATICS FOR SOCIAL JUSTICE

classroom. We therefore do not have much data to show how teachers were thinking about assessment in their projects.

Principle 6: Make inequity, power, and activism explicit parts of the curriculum. This principle includes making social justice issues explicit in the curriculum issues, helping students name and deal with individual, structural, and systemic inequities by making these issues "discussable" in school, and modeling activism with students.

The water project was designed to focus on this principle. The students and teachers tackled issues of inequity by considering how globally, not everyone had ready access to clean water, and promoted activism through their poster and multimedia campaign.

\section{Lessons Learned from the Radical Math Study Group}

The Radical Math Study Group in 2008-9 was a pilot project for us, a first step towards supporting teachers in developing an inquiry stance and a social justice approach towards their mathematics teaching. Our collaborative inquiry projects with the school and district staff helped us learn more about what it means to teach mathematics for social justice in an urban, Canadian elementary school. The primary teachers (kindergarten and Grade 2) designed a project that brought parent and community knowledge about numbers and the natural world as an object of study. Students were encouraged to make personal and cultural connections to the counting numbers from 1 to 20. The Grade 4 project allowed students who were English Language Learners to identify proudly with their linguistic heritage and to be positioned as experts around languages, as they grappled with demanding mathematical concepts in the area of data management. The Grade 5 project was integrated with social studies, literacy and visual 


\section{TEACHING MATHEMATICS FOR SOCIAL JUSTICE}

arts, and used mathematical investigations around volume and capacity and proportional reasoning to investigate issues of sustainability and access to clean water.

We found that the study group process ended up emphasizing some aspects of teaching for social justice - in particular, bringing social justice issues explicitly into the curriculum, building on student interests and experiences, and working with families and community. Other equally important dimensions - diversifying assessment, bridging skills and teaching gaps, and enabling significant work within communities of learners were given comparatively little (if any) attention. We speculate that in the study group, we focused on what was most typical of the collaborative work we had engaged in as teachers: designing novel and engaging activities. We did not spend very much time focusing on the details of classroom practice and pedagogy that are so critical to the equitable functioning of a classroom. For example, we didn't discuss participation structures or assessing student learning. Perhaps if we had collaboratively examined records of practice such as classroom video or student work, we might have embarked on more conversations about these other principles.

Although our study was small in scale and doesn't assume broad implications, nonetheless, the type of professional learning the teachers encountered through this process of collaborating on works in progress was promising. We were able to see the benefits of a model of PD where teachers are involved in research based on their current classroom context rather than on a prepackaged intervention or a narrow agenda.

Further, the impact of the study group goes beyond the design of a few new lessons that combine social justice and mathematics to the promotion of an inquiry stance amongst teachers. As Cochran-Smith (2004) points out, teaching for social justice is not a 
TEACHING MATHEMATICS FOR SOCIAL JUSTICE

fixed endpoint. Instead, it is a process of continuously facing dilemmas and adopting an inquiry stance about how to resolve these dilemmas. The greatest benefit of such a professional development project will not be the actual lessons that were created, but the development of a community of teachers who can collaboratively continue to learn about mathematics, social justice, and education.

Thus, although our initial goals for the project were to integrate social justice issues into the mathematics curriculum (Principle 6), we found that our work touched on many other principles of teaching for social justice along the way, as we began to tackle some of the dilemmas of mathematics teaching in the school. In this way, our goals for this initial study were met, and the momentum generated from our pilot study provided a strong foundation that carried over to the following year in which many of the teachers continued their commitment to professional learning about equitable mathematics teaching. This commitment lies at the heart of teaching for social justice. Although further research into student learning and participation in these innovative curriculum projects is also necessary, this pilot project was able to show the ways in which the study group participants were able to conceptualize and put into practice an equitable mathematics pedagogy. 
TEACHING MATHEMATICS FOR SOCIAL JUSTICE

\section{References}

Banks, C. A. M., \& Banks, J. A. (1995). Equity pedagogy: An essential component of multicultural education. Theory into Practice, 34(3), 152-58.

Brenner, M. E. (1994). A communication framework for mathematics: Exemplary instruction for culturally and linguistically diverse students. In B. McLeod (Ed.), Language and learning: Educating linguistically diverse students (pp. 233-267). Albany: SUNY Press.

Civil, M. (2007). Building on community knowledge: An avenue to equity in mathematics education. In N. S. Nasir, \& P. Cobb (Eds.), Improving access to mathematics: Diversity and equity in the classroom (pp. 105-117). New York, NY: Teachers College Press.

Cochran-Smith, M. (2004). Walking the road: Race, diversity, and social justice in teacher education. New York: Teachers College Press.

D'Ambrosio, U. (1997). Ethnomathematics and its place in the history and pedagogy of mathematics. In A. B. Powell, \& M. Frankenstein (Eds.), Ethnomathematics: Challenging eurocentrism in mathematics education (pp. 13-24). Albany, NY: SUNY Press.

Freire, P. (1993). Pedagogy of the oppressed (New revised ed.). New York: The Continuum Publishing Company.

Gonzalez, N., Moll, L. C., \& Amanti, C. (Eds.). (2005). Funds of knowledge: Theorizing practices in households and classrooms. Mahweh, NJ: Lawrence Erlbaum Associates. 


\section{TEACHING MATHEMATICS FOR SOCIAL JUSTICE}

Gutierrez, R. (2007). (Re)defining equity: The importance of a critical perspective. In N. S. Nasir, \& P. Cobb (Eds.), Improving access to mathematics: Diversity and equity in the classroom (pp. 37-50). New York: Teachers College Press.

Gutierrez, R. (2008). A "gap-gazing" fetish in mathematics education? Problematizing research on the achievement gap. Journal for Research in Mathematics Education, 39(4), 357-364.

Gutstein, E. (2006). Reading and writing the world with mathematics: Toward a pedagogy for social justice. New York: Routledge.

Ladson-Billings, G. (1995). Towards a theory of culturally relevant pedagogy. American Educational Research Journal, 32(3), 465-491.

Lee, J. (2002). Racial and ethnic achievement gap trends: Reversing the progress toward equity? Educational Researcher, 31(1), 3-12.

Masingila, J. O., \& King, K. J. (1997). Using ethnomathematics as a classroom tool. In J. Trentacosta, \& M.J. Kenney, (Eds.), Multicultural and gender equity in the mathematics classroom: The gift of diversity (pp. 115-120). Reston, VA: NCTM.

Moses, R. P., \& Cobb, C. E. (2001). Radical equations: Math literacy and civil rights. Boston: Beacon Press.

Takeuchi, M., \& Esmonde, I. (2010). Mathematics classroom organization and learning opportunities for English language learners. Annual Meeting of the American Educational Research Association, Denver, CO.

Walshaw, M. (2005). Getting political and unraveling layers of gendered mathematical identifications. Cambridge Journal of Education, 35(1), 19-34. 
TEACHING MATHEMATICS FOR SOCIAL JUSTICE

\section{Author Note}

This work is partially based on a presentation at the National Council for Teachers of Mathematics Research Pre-Session, April 2010. The research was supported by a grant from the Council of Ontario Directors of Education. Any opinions, findings, and conclusions or recommendations expressed in this material are those of the authors and do not necessarily reflect the position, policy, or endorsement of the Council of Ontario Directors of Education.

We would like to thank Rubén Gaztambide-Fernández, Joseph Flessa, Lance T. McCready, and Roland S. Coloma for their thoughtful critique of earlier versions of this manuscript. We would also like to thank the students and teachers of the Radical Math Study Group who generously donated their time to this project.

Correspondence concerning this article should be addressed to Indigo Esmonde, Ontario Institute for Studies in Education, University of Toronto, 252 Bloor St. W., Toronto, Ontario, Canada, M5S 1V6. Electronic mail may be sent to iesmonde@oise.utoronto.ca. 